\title{
CODE MIXING AND CODE SWITCHING IN THE EFL CLASSROOM INTERACTION
}

\author{
ANDI ASRIFAN \\ andiasrifan@gmail.com
}

\begin{abstract}
This research aims at finding out code mixing and code switching in the classroom interaction in terms of the teacher talk and the student talk at SMP Negeri 2 Parepare. In detail, this research aims to identify (1) the teacher talk particularly the type token ratio, the mean length of utterance as formal features, question, feedback and correction as interactional features, (2) the students talk particularly response to question and ask question as well as the students' preference towards the use of code mixing and code switching the students in learning achievement.

The research employed mix method research design. The subjects consisted of the teacher and the students. There is 1 teacher and 81 students which are divided into three classes. Each class consists of 27 students. The research data were collected by non-participant observation which was analyzed by using formal features, interactional features, descriptive and inferential statistics through SPSS 21.0.

The research result indicated that (1) the type token ratio in code mixing and code switching Indonesian/English in classroom interaction varied. It reveals that the vocabulary used by the teacher varied, (2) the speech of the teacher when addressing the students in the classroom by mixing and switching the language contained longer utterance, (3) the teacher used convergent and divergent questions in mix and switch the language when addressing students in the classroom interaction, (4) the teacher provided interactional corrective feedback and correction in mixing and switching the language when addressing students in the classroom interaction, (5) there are three reasons why the teacher mix and switch the code in the classroom interaction namely to give clear explanation to the students, to make the students easy to understand, and make the teacher and the students close to each other, (6) There are two types of students in response to the question namely the role of students to the teacher (S-T) and the role of students to students (S-S) in code mixing and code switching in the classroom interaction, (7) there are two types of the students question in code mixing and switching of Indonesian/English when asking the teacher namely procedural questions and convergent questions, (8) the students' preference towards the use of code mixing and code switching in the students learning achievement consist of two main points in this research namely, first the use of code mixing and switching convince positive attitude and second positive role to the students preference towards the use of code mixing and switching the students in learning achievement.
\end{abstract}


Keyword:

Code Mixing, Code Switching, Classroom Interaction (Student Talk, and

Teacher Talk).

\section{INTRODUCTION}

People may share their ideas in voice, interaction and conversation during language development in communication. In conversation, the mixture and move may happen in the same round or, if change in environment, interlocutor, dialog objectives and other social factors leads to a shift to another register, people may communicate and perform certain functions. You should offer your idea and enjoy the discussion to the other people. In addition, these tasks are carried out within the social context. A speaker will choose a special way to argue about not only his motive and his level of emotion, but also who he is talking about and what his relationship with the individual is like.

Language users in the conversation classroom contact are most often bilingual in as much as they often learn and use the language of the local group in addition to using the sign language of their community. In the Benjamin study (2009), bilingual people usually mix and change their languages, i.e. use elements or structures from each of their languages, when they interact with each other. Mixing and adjustment may be a conscious or unconscious mechanism because sociolinguistic influences such as the interlocker, the situational environment and language preference are influenced.

In order to understand the students, the phenomenon of bilingual teaching uses primarily code-mixing, and the changing of words and sentence type. It is common knowledge that bilingual education in schools is switching its 2 languages but it does not often recognize bilingual education as a grammatical form of expression in the EFL sense and globalization. Often people feel that it is not possible to break the two languages. Moreover, even researchers have not abandoned the concept of the long term un-systematic code mixing and code switching.

The other reasons for the instructor to mix and match words or phrases are to give the students specific examples and information. They may use their mother tongue or native language to receive and provide information. Many teachers now learn several languages, including their mother tongue and their second language. In our daily lives, though, we talk for many reasons, some of which have to do with each other as an individual, while others have to do with sharing knowledge or looking for practical results. With regard to the interaction in classrooms, the teacher will mix and switch his concept by speaking for many reasons, such as having the students understand well and reduce their differences.

Code-mixing and changing interaction in the classroom is particularly topical and relevant in terms of teachers' talk and students' talk because most of the teachers and students are talking in two or more languages. It is the key one and several 
researchers have carried out a research on mixing and switching, but they have done it by analyzing the experiences in the classroom, which have to do with the reasons and types for the school change; research has very little to do with changed codes in teachers, such as formal and interactional features.

This analysis also draws together contributions from different sociolinguistic contexts in which this phenomenon is found in the relationship between the classroom. The teacher discussion is about the form token ratio, the average duration, and the kinds of questions, suggestions and corrections in mixing and modifying the code at Junior High School. Also the interest of the writer to find a student for answers to questions, questions and a choice for the student.

The key speakers for teachers in describing materials and the classroom are between the teacher's talk and the student's talk, mixing and switching codes. In addition, teachers help create a particular kind of linguistic code, apart from the class discourse regulated. The longitudinal study of Science Teachers in an ESL environment conducted by Moje in Walsh (2006) suggests that teachers build a voice culture in which the use of language (i.e. teachers) facilitates or prevents association with that community among students. In his emphasis on learning sufficient scientific vocabulary, Moje suggested that students learned to speak science and that students advance quicker and better if they have adequate language skills. In this case, the teacher used the code for learning science to make it easier for students to understand. It is so important for teaching and learning because language is highly managed in the classroom.

Brice (2000) says that EFL/ESL classroom code switches have also begun to receive increasing attention worldwide. Code switching can be illustrated across the whole spectrum of competence as a normal phenomenon in ESL/EFL learning and training. Research seems to indicate that modified teachers code can be a sophisticated language used for different pedagogical purposes, whether in a teacherled classroom debate or in teacher-student interaction. For student chat, the question and questions are answered by the student.

Code switchover (2009) is a common phenomenon in Then and Ting, which stretcher from every day and workplace to schools, in which languages in the teaching of content subjects such as history (Butzkamm, 1998), linguistics (Zabrodskaja, 2007) and sciences have been developed as official languages of education (Martin, 1999; Mwinsheikhe, 2003; Probyn, 2005). In his previous research in primary schools 4 and 5 in Brunei in Then and Ting (2006), Darussalam showed that the code shift is the most common in history, followed by science and geography with the least use in mathematics. The code is used in language classrooms to promote student understanding at different levels: the kindergarten, Flyman-Mattsson \& Burenhult (1999), the elementary, Gabusi (2008); Rethinasamy \& Johie) and universities (Greggio \& Gil, 2007; Liu, n.d.).

Ustunel teachers in Then and Ting (2009) also turn code to fix university class problems and silence. Alternatively, code switching represents a technique for 
professors to adapt to English, teaching purposes and teaching roles of students at universities in China but provides a better insight into the functions and types of code switches in their language study studies based on naturally occurring classroom results. To that end, a semantic code-switching model developed by Gumperz (1982) is an interesting way to explore social and cultural roles and significances of language use in the context of learning, such as interactive problem-solving experiences and the conversations of school children.

Studying a speech in a classroom is a fascinating theme for the purpose of teaching and learning. Teachers in the field of teaching are challenged to make students understand and achieve the aim of learning English, but many teachers say that one way to use it is to modify words in the teacher's talk and to speed up the generation of well-known words and sentences. The choice of bilingual speakers when teaching is fascinating. It is interchangeable. There are, however, reasons that facilitate language mixing and switching and often can involve language switching so that the exact semántic message that the speaker wishes to convey is transmitted. For instance, a change can happen because the language the speaker moves from English to Indonesian or Indonesian to English is not formally defined in the base language (Grosjean in Ludmila. at all, 2009).

Code mixing, code swapping, teacher talking and student talk are main elements which are not separable, also in SMP Negeri 2 Parepare there has been a teacher who is mingling in the classroom and switching languages, but who does not speak English. As the researcher knows, teacher expression is the unique language teachers use in the teaching classroom when using the English language and when learning the student. In order to accomplish this aim, teachers obviously need to mix together and turn to the school to discuss new materials for their students. The relationship between the study of the teacher's language changing code speaks in particular about the formal and interactional features in the interaction between language classrooms. In addition, it creates responses to questions and questions from the student speech by modifying the language of the students to the use of code switching and the combination of code for student success.

Many researchers have studied the mixing and switching of code, for example, increasing students' word levels, promoting meaningful educational success, encouraging standard English masterships and teaches in interaction with the lessons, but very little is known about the way in which code switches are used to convey teachers' conversations.

This way the writer investigates how to mix the code and switch the teacher talk to type of token ratio, the average length and the kind of questions, feedback and correction, the student's response to changes in the teacher's way, and the student talk at SMP Negeri 2. The teacher finds that the teaching staff at June. Besides, the author must know how to mix and adjust the choice of the students to use the code mixing and switching within the students. The other reasons for the writer to use the code of the conversation of the teachers and the student talk is that the writers feel that a lot of 
study has been done on the topic of teacher conversations and student conversation, but the writer never noticed it in relation to mixing and switching the phrases (Ike, 2010 and Puasa, 2010). This investigation is also of interest, since the writer knows that bilingual schools are the most difficult school today, many schools want to be bilingual and can be international.

This research examines code mixing and switching from one professor of Biology to another because speech community like code is often used in science lessons for introducing and the materials first, but then the teacher attempts to make the students understand language usage so that we rarely find that all terms are explained without switching code. The writer is difficult to locate the code from this assertion (Walsh, 2006). In addition, by considering modifying the teacher speak, student discussion, and argues that such studes allow us to better understand the usage of formal and interactional features in language, the author wants to examine student discussion in terms of answers to queries, questions, and the desires of students for the use of code mix and code change in the student's achievement. Besides, talk about the student talk, it refers to investigate the students' preference related to code mix and switch is used by the teacher, and the students response the way teacher mixes and switches language as well as student talk in response a questions and asking questions in mixing and switching the teacher talk and student talk in Junior High School particularly at SMP Negeri 2 Parepare.

\section{Some Pertinent Ideas}

In this research the writer concludes that:

1. Code is a language, a variety of language, sign, and an interaction tool to other people it's sometimes in written and spoken.

2. Code switching is a variety of language which is used in conversation that consists of two or more languages and it is used in the level of sentences. For example "I like learning English and Match tapi kadang-kadang saya sangat sulit untuk memahaminya".

3. Code mixing is a variety of language which is used in conversation that consists of two or more languages, it is used in the level of words.

4. There are two functions of code mixing and switching in the classroom interaction such us function of the teacher and the students.

5. Teacher talk is the language used by the teacher to handle class in teaching foreign or English as a second language to achieve target language comprehensible input and has its own special style.

6. There are two items for the features of teacher's talk namely formal and interactional features. There are four kinds of interactional features namely questions, feedback and correction. 
7. Student talk is language use of the students in classroom interaction either with teacher, or their mate. There are two elements of student's interaction with teacher and classmates namely response to questions and ask questions.

8. The students' preference refers to attitudes while attitude contain three elementary components: cognitive, feeling or affective and actions or behavior.

\section{Method and Design of the Research}

Qualitative quantitative approach is the method of this study. This method is referred to as exploratory mixed approach design, according to Gai, Mills \& Airasian (2006), qualitative data is collected first and quantitative analysis further supports the findings from qualitative analysis. It is used to investigate, define, and explain the interactive and formal features of teachers' lectures in the relationship between the classrooms. It is also used to define the students' preference for the use of the code for learning.

Study uses Discourse Analysis in terms of the methodology. The definition and interpretation of the spoken interaction is concerned here. This study focuses on the teacher speech and student speech in the relationship between the classrooms (McKarthy, 1991:12). The writer uses Likert Scale and his statement in a questionnaire to define the preference of students particularly in the attitude of the student.

\section{Subject}

The subject of this research is the teacher and the students at SMP Negeri 2 Parepare. For teacher, there are one subject of this research and teach in class VII. She is a Biology teacher which is taken by randomly. For students, the writer takes three classes namely VIIA, VII.C and VII.E. The writer takes them because those classes are bilingual which is very potential to find the students' preference related to the Biology and it is interest class to find out the students' preference towards the use of code mixing and switching in their learning.

Biology teacher is a female and experience with over 14 years' experience. He teaches six classes in the first grade namely VII.A, VII.B, VII.C, VII.D, and VII.E. She also teaches in the third grade particularly in acceleration class.

The writer takes one subject of teachers in SMP N 6 Makassar is aimed to find out the code mixing and switching words of teacher talk in formal and interactional features in the classroom interaction which are getting from Biology lesson and the student talk response to question and ask question, as well as the students' preference towards the use of code mixing and code switching in the students learning achievement. Here, the writer will look at the use of code mixing and code switching of teacher in explaining materials "English to Indonesian or Indonesian to English", it aims to give new information or explain the same terms only in teaching. It is also particularly find out first the formal features in terms of type token ratio and the mean length, second the interactional features namely 
question, feedback and correction, third student responses to question and ask questions as well as the role of mix and switch words in teaching process.

\section{Instrument of the Research}

The instruments of the research are observation checklist, interview, recording by Sony video, and questionnaire. The observation checklist is aimed to find out code mixing and switching in the features of teacher talk and student talk. The recording is used to identify code mixing and switching in the formal and interactional features of teacher talk which occur while identify the student's response to question and ask question. The interviews are aimed to know and get information from the teacher such us why teachers use code mixing and switching in their talk as addition. The questionnaire is used to find the students' preference towards the use of code mixing and code switching in the students learning achievement.

\section{Data Analysis}

\section{Formal Features Analysis}

a. The Type Token Ratio

The type token ratio is calculated for each class. The ratio is obtained by dividing the total number of different words occurring in the utterance by its token (the total number of words) in mixing and switching words. AntConc Software is used to find out the total number of different words and the total number words in mixing and switching of the teachers. Then the ratio is calculated by using the following formula:

$$
\text { TTR }=\frac{\text { The number of different words in mix and switch words }}{\text { Total number of words in mix and switch words }}
$$

Owen (1996)

To provide definite and operational specification of this features, and to be able to give more comprehensive and meaningful interpretation is used:

1. The variety of vocabulary $<0.59$ is regarded less varied

2. The variety of vocabulary $\geq 0.59$ is regarded varied

b. Mean Length of Utterance (MLU)

The mean length of utterance is measured per utterance. The formula of calculating the word is as follows:

$$
\text { Total number words }
$$


Total number of utterance

Lin (2005)

Mean length of utterance proposed by Choudron (1988) is used for interpretation:

1. The mean length of utterance $<9.01$ words per utterance (wpu) shows the mixing and switching words contained averagely shorter utterances.

2. The mean length of utterance $\geq 9.01$ words per utterance (wpu) shows the mixing and switching words contained averagely shorter utterances.

\section{Interactional Features Analysis}

a. Questions

The analysis of the questions is done by using the model proposed by Richard and Lockhart. The questions used by teachers address students in categories namely procedural question, convergent question, and divergent question.

b. Feedback and Correction.

The analysis of feedback and correction there two main categories are taken into account namely interactional feedback and corrective feedback. Garcia's model (2005) she divided into several terms such us indicating an incorrect answer, praising, modifying a student's answer, repeating, summarizing, and criticizing. Another feedback is corrective feedback. Tedick and Barbara (1998) divided corrective feedback into explicit correction, clarification request, elicitation, and repetition.

\section{The Students Response to Questions and Ask Questions}

a. The Students Response to Questions

Talking about the students' response to question and ask question it's related to Brock. According Brock (1986), he found that higher frequencies of referential questions asked by teachers would have some effects on classroom discourse: students' responses to display questions would be shorter and syntactically less complex than their responses to referential questions; confirmation checks and clarification requests by the teacher would occur more frequently following referential questions than following display questions.

b. The Students Ask Questions

Asking questions of the student is refers to the reason students ask, it may be answered by yes-no question of further information. The question may begin with "what" concern with factual matters or "how and why" to explore the process and reason.

\section{The Students' Preference Towards the Use of Code Mixing and Switching in the Students Learning Achievement}


The data were drawn from a tabulated questionnaire and then evaluated at Likert Scale. At this stage, he wanted to discover how students prefer code mixing and code switching to 15 issues in students learning achievement and he strongly agreed (SS), agreed (ST), undecided (SM), disagree (TS), and strongly disagreed (SS). Heaton (1988) categorization (STS). She says BAT in Olugbara (2008) (Biology Achievement Test). Olugbara notes that after researching the subject of biology learning the data provided about the BAT emanated from the student.

When students are able to find the preference to the use of code mixing and code switching between three classes following the analysis, after entering data in Microsoft Excel, SPSS is used. It is important as Excel allows data entry simpler than SPSS, but has less mathematical analytical resources than SPSS. This conversion is essential. This combination of statistical tools has therefore allowed rigorous entry and analysis of data. In addition, the average score and the standard deviation are important for comparing students' preference for code mixing to the shift in learning results. The t-test is excluded as the writer used the coherence study of the improvement of the mean score and the usual difference of both groups.

Here, after students have been exposed to their respective therapies, biological milestones have been made. To decide whether the student's preference for biology by Indonesia English and English teaches Indonesia mixing and changing codes is statistically important. Data would thus be evaluated by means of coherence progress for the student preference. Automatically, the code mix and change are best used for teaching and learning biology for students who achieve a good score in BAT and a high value of attitude (preference of students).

\section{Findings}

\section{Teachers' Speech}

\section{a. The Formal Features}

1) The type token ratio in the teachers' speech when explaining materials with mix and switch the language Indonesian English and English Indonesian to the students in the classroom interaction.

Having transcribed the teachers' speech in the classroom, the writer used Antconc Software to calculate the number of different words as well as the total number of words in the teachers' speech. The total number of different words (type) was then divided by the total number of words (token) to obtain the result of typetoken ratio in the teachers' speech when explaining materials with mix and switch the language Indonesian English and English Indonesian to the students in the classroom interaction. The results of calculation showed that the teacher has different type token 
ratio in each class namely class VIIA, class VIIC, and VIIE. It is shown in the table 1 below:

Table 1. Type-Token Ratio

\begin{tabular}{llll}
\hline \multirow{1}{*}{ Observation } & \multicolumn{3}{c}{ Type-token ratio } \\
\cline { 2 - 4 } & \multicolumn{1}{c}{ VIIA } & VIIC & VIIE \\
\hline Explanation of the & Types: 81 & Types: 95 & Types: 58 \\
teacher in mixing & Token:106 & Token: 146 & Token: 92 \\
and switching & Ratio: 0.764 & Ratio: 0.650 & Ratio: 0.630 \\
language. & & & \\
\hline
\end{tabular}

2) The Mean Length of Utterance in the Teachers' Speech When Explaining Materials With Mix and Switch the Language Indonesian English and English Indonesian to the Students in the Classroom Interaction

In finding out the mean length of utterance of the teacher's speech when explaining materials with mix and switch the language Indonesian English and English Indonesian to the students in the classroom interaction, the writer calculated the mean length of Indonesian utterance first, English is second, and the third is Indonesian/English utterance. It was used as a measure of sentences level complexity. It is calculated by dividing the total number words of Indonesian, English, and Indonesian/English with the total utterance of the three languages in the all classes. The results of complexity were presented in table below:

Table 2. Mean Length of Indonesian Utterance

\begin{tabular}{llll}
\hline \multirow{2}{*}{ Observation } & \multicolumn{3}{c}{ Type-token ratio } \\
\cline { 2 - 4 } & VIIA $(\mathrm{wpu})$ & VIIC $(\mathrm{wpu})$ & VIIE $(\mathrm{wpu})$ \\
\hline Explanation of & Token: 20 & Token: 5 & Token: 3 \\
the teacher in & Total Utterance: 8 & Total Utterance: 2 & Total Utterance: 2 \\
Indonesian & MLU: 2.5 & MLU: 2.5 & MLU: 1.5 \\
language. & & & \\
\hline
\end{tabular}

Table 3. Mean Length of English Utterance

\begin{tabular}{llll}
\hline \multirow{2}{*}{ Observation } & \multicolumn{3}{c}{ Type-token ratio } \\
\cline { 2 - 4 } & VIIA $(\mathrm{wpu})$ & VIIC $(\mathrm{wpu})$ & VIIE $(\mathrm{wpu})$ \\
\hline Explanation of & Token:597 & Token: 362 & Token: 102 \\
the teacher in & Total Utterance: 101 & Total Utterance: 59 & Total Utterance: 20 \\
English & MLU:5.911 & MLU: 6.135 & MLU: 5.1 \\
\hline
\end{tabular}


language.

Table 4. Mean Length of Indonesian/English Utterance

\begin{tabular}{|c|c|c|c|}
\hline \multirow{2}{*}{ Observation } & \multicolumn{3}{|c|}{ Type-token ratio } \\
\hline & VIIA (wpu) & VIIC (wpu) & VIIE (wpu) \\
\hline Explanation of the & Token:106 & Token: 146 & Token: 92 \\
\hline $\begin{array}{l}\text { teacher in mixing } \\
\text { and switching } \\
\text { language }\end{array}$ & $\begin{array}{l}\text { Total Utterance: } 9 \\
\text { MLU: } 11.77\end{array}$ & $\begin{array}{l}\text { Total Utterance: } 13 \\
\text { MLU: } 11.23\end{array}$ & $\begin{array}{l}\text { Total Utterance: } 9 \\
\text { MLU: } 10.22\end{array}$ \\
\hline
\end{tabular}

b. The Interactional Features

1) The Types of Questions Asked By the Teacher in the Classroom Interaction

Having transcribed the teachers' speech in the classroom, it was found out that there were three types of questions used by the teacher in the three classes. The questions are procedural, convergent, and divergent questions.

Table 5. Teachers' Question

\begin{tabular}{cccc}
\hline Question & Class VIIA & Class VIIC & Class VIIE \\
\hline Procedural Question & - & - & - \\
Convergent Question & 1 & - & - \\
Divergent Question & 3 & 3 & 2 \\
\hline
\end{tabular}

2) The Types of Feedback and Correction Provided By the Teacher in the Classroom Interaction

The types of feedback and correction provided by the teacher in the classroom interaction have done in the three classes, the example will be given below:

The types of feedback:

1. "Apa you? ya good!" (Indonesian/English code switching) (What? Yah good!)

2. “Terganggu, Ok.” (Indonesian/English code switching) (Disturbing, Ok)

"Gatal2, can be" (Indonesian/English code switching)

"Itching can be"

The types of correction: 
1. "If I do seperti itu, in my opinion the animal will lose their food." (Indonesian/English code mixing)

(If I do like that, in my opinion the animal will lose their food.)

2. "To safe from water pollution seperti don't throw garbage in everywhere. " (Indonesian/English code mixing)

(To safe from water pollution for example do not throw garbage in everywhere)

3. "Artinya, may be someday akan terjadi bencana alam because mineral sudah berbaur with the water in the sea, so the fish can die."

(Indonesian/English code mixing)

(It means that, maybe someday will occur disaster because mineral has decomposed with the water in the sea, so the fish can die)

4. "Give punishment means memberikan hukuman." (Indonesian/English code switching)

(Give punishment means giving punishment)

5. "You can say give punishment to the people with melanggar this rules." (Indonesian/English code mixing)

(You can say give punishment to the people with break the law)

6. "Makes rules means buat aturan yang akan memberikan dampak

lingkungan yang bagus because the people will takut untuk membuat

pelanggaran." (Indonesian/English code mixing)

(Makes rules means. Making rules that can give a good impact for our environment because the people will scare in breaking the law)

7. “Mengurangi decrease." (Indonesian/English code switching)

(Decrease decrease).

\section{The Reason for the Teacher in the Use of Code Mixing and Code Switching in Learning Achievement}

To find out why the teacher blends and changes the language to accomplish learning. The author used an interview that was organized. It means that before the instructor is interviewed, the writer sets questions. The interview results show the teacher three reasons why code mixing and code shifting is employed in learning, particularly in the interaction between classes, namely to give students simple explications in harsh words (technical terms), to enable students to understand and to make the teacher and students close one another. The use of code mixing and code switching in learning often provides strong indications that students have a greater faith in English, that the students have an understandable feedback and that they are compatible with the Krashen $i+1$ hypothesis. (Herzegovina, 1985)

Obviously, when in a bilingual class English is needed to be used in the sciences, teacher need a mix and a change of language to clarify the vocabulary of the lesson, which is very difficult for the student to understand in the interaction of the 
class. Furthermore, the students love mingling the teachers and changing terms in learning, so that they can simply answer the teacher's questions directly.

\section{Students' Speech}

In the students' speech there are two important things namely:

a. The Students Response to Questions

1) Class VIIA

In the first class, there are two students' responses of the question but it is occur in the role of students such us students to students $(\mathrm{S}-\mathrm{S})$ when they are discussing about the topic which are given by the teacher. The example below:

1. "I will give suggestion to her or him and menjelaskan about dampak damage of environment." (Indonesian/English code mixing)

(I will give suggestion to her or him and explain about the damage impact of our environment)

2. “The animal can't live if there are no trees because it is sangat diperlukan untuk kehidupan." (Indonesian/English code switching)

(The animal can't live if there are no trees because they are very necessary for our live)

3. "In my opinion hal itu not good for us" (Indonesian/English code mixing) (In my opinion it is not good for us)

4. "Saya akan menjelaskan about the activity seperti merokok, menebang pohon, transportasi yang mengakibatkan air pollution." (Indonesian/English code mixing)

(I will explain about the activity for example smoking, cut the trees, and

2) Class VIIC transportation that caused air pollution).

The role of students in the class VIIC is different in the first class. Clearly, in this class, there are many students' responses that occur either students to students (S$\mathrm{S})$, or students to teacher (S-T). The example given below:

1. "Mom, yang ini environment." (Indonesian/English code mixing) (Mom, this is environment)

2. "I have flu." (Indonesian/English code switching) (I get a cold)

3. "Mom nda ada gambarnya, mom." (Indonesian/English code mixing) (Mom, there is no the picture mom)

4. “No groupku mom." (Indonesian/English code mixing) (I don't have group mom)

5. “Mengurangi minimize." (Indonesian/English code switching) (Decreasing, minimize) 
6. "Jawaban kami adalah don't put garbage in everywhere and in the river." (Indonesian/English code switching)

(My answer is don't put garbage in the everywhere and in the river)

7. "Give punishment bagi yang melanggar." (Indonesian/English code switching)

(Give punishment to the people who break)

8. "Mom, finishmi, mom." (Indonesian/English code mixing)

(Mom, I have finished, mom)

9. "After watching that film, Can you offer some solution that can solve the problem?

If yes, please mention and explain it. If no, please explain why. Yes, after watching that film, we can solve the problem and mengurangi pollution." (Indonesian/English code mixing)

(After watching that film, Can you offer some solution that can solve the problem?

If yes, please mention and explain it. If no, please explain why. Yes, after watching that film, we can solve the problem and decrease the pollution.)

10. "After saw that film, Can you give some cause effect of air pollution?

If yes, please mention and explain it. If no, please explain. Yes after see the film because effect of air pollution is smoke, makes asma." (Indonesian/English code switching)

(After saw that film, Can you give some cause effect of air pollution?

If yes, please mention and explain it. If no, please explain. Yes after see the film because the effect of air pollution is smoke, makes asthma)

\section{3) Class VIIE}

The role of students in the class VIIE is similar to in the class VIIC. Clearly, in this class, there are students' responses that occur either students to students (S-S), or students to teacher (S-T). Some examples are given below:

1. "The government have implementing trus..." (Indonesian/English code switching)

(The government has implemented then...)

2. "To save our environment ehm mineral in land, and apa sich and \# fertilizer, do not trhow the plastic yang tidak dapat dicerna eh diuraikan oleh alam." (Indonesian/English code mixing)

(To save our environment, mineral in land, and what's and \# fertilizer, do not throw the plastic that cannot be decomposed by nature)

\section{4) The Students Ask Questions}

Asking questions of the student is refers to the reason students ask, it may be answered by yes-no question of further information. The question may begin with "what" concern with factual matters or "how and why" to explore the process and 
reason. The example of responses occurred in the three classes will be presented below:

\section{4) Class VIIA}

In the class VIIA, the students ask question much given a questions which are needed answer yes-no questions and referential questions. The example namely:

1. "Mom, apa Englishnya gempa bumi mom?" (Indonesian/English code mixing)

(Mom, what is the English of earthquake, mom)

2. "What is the title... apa?" (Indonesian/English code switching) (What is the title what)

3. "Earthquake saya mom?" (Indonesian/English code mixing) (My part is earthquake, mom)

4. "Mom, apa Englishnya hutan mom?" (Indonesian/English code mixing) (Mom, what is the English of forest mom)

5. "Mom, apa maksudnya ini mom?” (Indonesian/English code mixing) (Mom, what is the meaning of this mom)

6. "What the solution for the \# apa\# land pollution?" (Indonesian/English code mixing) (What is the solution for the \#what\# land pollution)

7. “About film judulnya kah?” (Indonesian/English code switching) (Do your title about film)

\section{5) Class VIIC}

In the class VIIC, the questions occur is similar with class VIIA. Here, the students ask question much given a questions which are needed answer yes-no questions and referential questions. The example namely:

1. “Apa Englishnya sesak nafas, mom?” (Indonesian/English code switching)

(What is the English of out of break, mom?)

2. "Diputar ini, mom?" (Indonesian/English code switching) (Is it record, mom?)

3. "Yang mana, mom?" (Indonesian/English code switching) (Where is it, mom?)

4. “Apa judulnya, mom?” (Indonesian/English code switching) (What is the title, mom?)

2. "Apa Englishnya mom asap pabrik." (Indonesian/English code mixing) (What is the English of smoke factory, mom?)

3. "Apa Englishnya bau menyengat mom?" (Indonesian/English code mixing)

(What is the English of stink, mom)

4. "Dicopyki ini semuanya?" (Indonesian/English code switching) 
(We have to copy this all?)

5. "Apa mengurangi dalam bahasa English?" (Indonesian/English code switching)

(What is decrease in English?)

6. "Can you explain what we do to menghindari pollution." (Indonesian/English code mixing)

(Can you explain what we do to avoid pollution?)

\section{6) Class VIIE}

In the class VIIE, the questions of students that occur in two kinds of questions namely the question that only answers yes-no questions and referential questions. Te example given below:

1. "What we do so the forest can't flood eeh apa yang kita lakukan agar kerusakan hutan tidak menyebabkan banjir?" (Indonesian/English code switching)

(What we do so the forest cannot flood eh, what are we doing to avoid the damage of forest and the flood cannot occur)

2. "How to make a clean water apa..?" (Indonesian/English code switching) (How to make clean water what..?)

Teachers' speech and the students' speech are two elements that cannot be separated to each other. Clearly, in the classroom interaction there is always interaction both the teacher and the students in learning. The teachers' speech and the students' preference are very close to each other. The varied vocabularies in explaining material give the students have good score.

\section{The Students' Preference Towards the Use of Code Mixing and Switching in the Students Learning Achievement}

The questionnaires were made up of two sections, each section was done after the observation was finished. They are namely:

a. Biographical Information

The students who participated in this study were the students in SMP N 6 Makassar which consist of three classes. The number of students who participated in this research are 81 students, comprising 43 females and 38 males. The data concerning home language of the students showed that 69 students indicated Indonesian language, 7 indicated both Indonesian and English language as home languages, 2 indicated both Indonesian and Makassar language as home languages, 1 indicated English language as home language, 1 indicated both Indonesian and Java language as home language, and 1 indicated both Indonesian and Chinese language as his home languages. The number of students that indicated Indonesian as their home language was satisfactory to advance the study. The data collected therefore, were reliable for the study and the results could be drawn with looking at the students' preference in each classes. There are three classes in this study and all have given 
different views about the use of code mixing and code switching. However, on the question of what language(s) were spoken at school, 7 students indicated that they spoke Indonesian at school, 2 indicated English and 72 reported that they spoke both Indonesian and English. Moreover, on the question of what language(s) the biology teacher taught in, 28 students indicated that their teacher taught them in English, 0 indicated Indonesian and 53 indicated English and Indonesian. Furthermore, on the question of what language(s) the students learnt biology in, 10 students indicated that they learnt biology in English, 10 students indicated Indonesian and 61 indicated English and Indonesian. It is clear from this analysis that using code mixing and code switching is relevant to be done in enhancing the students learning achievement. Many students said using Indonesian English in teaching make us easy to understand English lesson and we can pass the exam with good grade point. Investigating Indonesian English code mixing and code switching in these communities, therefore, reveal very useful information that could assist in planning and policy. The decision which has done by the government in making the international standard school is very crucial and need backing from many sides.

b. Students Views about Biology

The students' views about biology were assessed to know the students' preference towards the use of code mixing and code switching in learning achievement by giving Biology Achievement Test (BAT) and questionnaire to know their feeling which consists of 13 questions. The questionnaire comprised a Likert type scale. On each question, students indicated their levels of agreement or disagreement with the given statements related to Biology attitudes. Scores on each question ranges from 1 to 5 , with lower values indicating more negative attitudes towards biology. The questionnaire scores could range from 20 to 100, a range of 80 points. A score higher than the midpoint of 37.5 indicated a relatively positive attitude towards biology and score lower than 37.5 indicated a relatively negative attitude. To verify whether there was any significant effect of Indonesian and English code mixing and switching on students' preference towards the use of code mixing and switching in learning achievement.

In finding out significant difference related the students' preference towards the use of code mixing and code switching in learning achievement, the writer decided mean score and standard deviation first and then correlated with the result questionnaire of the students.

1) The Mean Score and Standard Deviation of the Students' related to Biology Achievement Test (BAT).

After being calculated the result of the students' related to the BAT, the mean score and standard deviation are presented in the following table to find out the 
significant difference between the three classes in taught Biology towards the use of code mixing and code switching in learning achievement.

Table 6. The Mean Score and Standard Deviation of the Students' Preference Towards The Use Of Code Mixing And Code Switching In Learning Achievement.

\begin{tabular}{ccc}
\hline Class & Mean Score & Standard Deviation \\
\hline VIIA & 81.11 & 8.91 \\
VIIC & 73.70 & 10.43 \\
VIIE & 68.52 & 8.18 \\
\hline
\end{tabular}

2) The Mean Score and Standard Deviation of the Students' related to the attitude of the students (students' preference).

After being calculated the result of the students' related to the attitude of the students, the mean score and standard deviation are presented in the following table to find out the significant difference between the three classes in taught Biology towards the use of code mixing and code switching in learning achievement.

Table 7. The Mean Score and Standard Deviation of the Students' Preference towards the Use of Code Mixing and Code Switching in Learning Achievement

\begin{tabular}{ccc}
\hline Class & Mean Score & Standard Deviation \\
\hline VIIA & 52.30 & 4.90 \\
VIIC & 49.81 & 4.66 \\
VIIE & 49.26 & 5.55 \\
\hline
\end{tabular}

\section{The Student's Response towards the Use of Language That They Want in Learning Biology and Their Reason Why They Choose the Language}

a. The Student's Response towards the Use of Language That They Want in Learning Biology 
In this section presents preferences and explanations of these preferences regarding language(s) of instruction for the three classes and related to the question in which language(s) the students prefer biology to be taught at their school.

Table 8. The Student's Response towards the Use of Language That They Want in Learning Biology

\begin{tabular}{lcccccc}
\hline Language(s) & \multicolumn{5}{c}{ Number of the students } \\
\cline { 2 - 7 } & \multicolumn{2}{c}{ Class VIIA } & Class VIIC & Class VIIE \\
\cline { 2 - 7 } & $\mathrm{F}$ & $\%$ & $\mathrm{~F}$ & $\%$ & $\mathrm{~F}$ & $\%$ \\
\cline { 2 - 7 } & & - & 1 & 4 & 9 & 33 \\
Indonesian & 0 & 70 & 25 & 93 & 17 & 63 \\
Indonesian/English & 19 & 30 & 1 & 4 & 1 & 4 \\
English & 8 & 100 & 27 & 100 & 27 & 100 \\
Total response & 27 & & & & & \\
\hline
\end{tabular}

b. The Reason Why the Students Choose the Language

Different with the first section, in this section presents the explanation of the students' reason in regarding language(s) of instruction for the three classes and related to the question in why the students choose the language(s).

Table 9. The Explanation for Indonesian Language Preference for the Three Classes Related to the Reason Why the Students Choose the Language(s)

\begin{tabular}{lccc}
\hline Statements & \multicolumn{3}{c}{ Number of the students } \\
\cline { 2 - 4 } & Class VIIA & Class VIIC & Class VIIE \\
\cline { 2 - 4 } Makes Biology easy to understand & - & 1 & 7 \\
My Biology teacher teaches & - & - & 2 \\
biology in a clear and & & & 9 \\
understandable way & & & \\
Total response & & &
\end{tabular}


Table 10. The Explanation for Indonesian/English Language Preference for the Three Classes Related to the Reason Why the Students Choose the Language(s)

\begin{tabular}{lccc}
\hline \multirow{1}{*}{ Statements } & \multicolumn{3}{c}{ Number of the students } \\
\cline { 2 - 4 } & Class VIIA & Class VIIC & Class VIIE \\
\hline $\begin{array}{l}\text { My Biology teacher teaches } \\
\text { biology in a clear and } \\
\text { understandable way }\end{array}$ & 2 & 9 & 3 \\
$\begin{array}{l}\text { My Biology teacher makes } \\
\text { biology very interesting }\end{array}$ & 1 & 2 & 3 \\
$\begin{array}{l}\text { Learning Biology in English } \\
\text { increases my chances of passing }\end{array}$ & 9 & 4 & 5 \\
$\begin{array}{l}\text { English lesson } \\
\text { Learning Biology in English } \\
\text { increases my chances of getting a } \\
\text { good job after leaving school }\end{array}$ & 7 & 10 & 6 \\
\hline \multicolumn{1}{c}{ Total response } & & & \\
\hline
\end{tabular}

Table 11. The Explanation for English Language Preference for the Three Classes Related to the Reason Why the Students Choose the Language(s)

\begin{tabular}{lccc}
\hline Statements & \multicolumn{3}{c}{ Number of the students } \\
\cline { 2 - 4 } & Class VIIA & Class VIIC & Class VIIE \\
\hline $\begin{array}{l}\text { My Biology teacher makes biology very } \\
\text { interesting }\end{array}$ & 2 & - & - \\
$\begin{array}{l}\text { Learning Biology in English increases } \\
\text { my chances of passing English lesson }\end{array}$ & 2 & - & -
\end{tabular}


Learning Biology in English increases

my chances of getting a good job after leaving school

Total response

1. Teachers' Speech

a. The Formal Features

1) The Type Token Ratio in the Teachers' Speech When Explaining Materials With Mix and Switch the Language Indonesian English and English Indonesian to the Students in the Classroom Interaction.

The findings show that the average of type token ratio in the speech of teacher in class VIIA in mix and switch Indonesian/English was 0.764, in class VIIC was 0.650 , while the average of type token ratio in mix and switch Indonesian/English in class VIIE was 0.630 . It indicates that the speech of the teacher mix and switch Indonesian/English in class VIIA was more varied than the teachers' speech in VIIC and VIIE. However, since the average of type token ratio of the teachers' speech was $\geq 0.59$ in the three classes, the speech of the teacher was considered varied.

Clearly, the teacher speech in the three classes has varied of vocabulary even though the utterance or statement that has been given by the teacher is not complex in her explanation when code mixing and code switching occur. It refers to the Chaudron (1988) stated that type token ratio merely indicates variety rather that complexity.

2) The Mean Length of Utterance in the Teachers' Speech When Explaining Materials With Mix and Switch the Language Indonesian English and English Indonesian to the Students in the Classroom Interaction

The mean length of utterance in the teachers' speech when explaining materials with mix and switch the language Indonesian English and English Indonesian to the students in the three classes are different to each other. It is proved by the average MLU of teacher in class VIIA (11.77 wpu) which was longer than the teacher in class VIIC (11.23 wpu), and VIIE (10.22). Since the average MLU of the teacher in the three classes was $\geq 9.01 \mathrm{wpu}$, it indicates that the speech of the teacher in the three classes contained averagely longer utterance when explaining material in mixing and switching Indonesian/English to the students in the classroom interaction. While the mean length of the teacher speech in English and Indonesian is shorter 
utterance because the mean length of the teacher speech in two classes was $<9.01$ wpu.

These findings seem to provide a good indication. Longer utterances usually contain more concepts and idea that shorter utterance as stated by Choudron (1988). Therefore, the use of longer utterance by the teacher can provide a large amount of input for the students particularly in learning Biology.

b. The Interactional Features

1) The Types of Questions Asked By the Teacher in the Classroom Interaction

The types of questions asked by the teacher in the three classes consist of three types of questions namely procedural, convergent, and divergent questions. The findings showed that the teacher asks in the class VIIA 1 convergent question and 3 divergent questions in mixing and switching Indonesian/English. Different with the teacher ask in the class VIIC and VIIE. Both two classes VIIC and VIIE have 3 divergent question only, neither procedural question nor convergent question when she explains in mixing and switching Indonesian/English in the classroom interaction. It is not refers to Richard and Lockhart (1994) pointed out that teacher tend to ask more convergent questions than divergent question.

2) The Types of Feedback and Correction Provided By the Teacher in the Classroom Interaction

Talking about the types of feedback and correction by the teacher in the classroom interaction, it reveals in finding that the teacher use feedback and correction in the three classes. There are 3 feedbacks and 7 corrections occurred in the three classes. Mostly the types of feedback are interactional feedback to the students namely expanding or modifying students' answer, indicating an incorrect answers, and comment.

\section{The Students' Speech}

a. The Students Response to Questions

Talking about the students' response to question in SMPN 6 Makassar, based on the findings given, the response of the students covered responses to referential questions; confirmation checks and clarification requests (Brock, 1986). The responses of students are different in each class. In each class, there are two roles of students in response the question namely the role of students to the teacher (S-T) and the role of students to students (S-S) in code mixing and code switching in the classroom interaction. In the class VIIA there are 4 responses to the divergent questions and there is no response to referential questions or needed yes-no answer. Contradict with the class VIIC, in this class there are 4 responses to the divergent questions, there are 6 response to the referential questions or the questions that are 
needed yes-no answer. In the class VIIE, there are only responses to the divergent questions, neither referential question, nor convergent question.

b. The Students Ask Question

The students ask question in the classroom interaction is the main point in the classroom interaction. Here, the students ask question in each class is very different. In the class VIIA, the question much given questions which are needed answer yes-no questions and referential questions. There are 5 referential questions, and 2 questions that are needed yes-no answer. In the class VIIC, there are 6 referential questions, and 3 questions that are needed yes-no answer. In the class VIIE, there are 2 students ask divergent questions, neither referential question nor the question that is needed yes-no answer. It is refers to Barnes (in Yan, 2006:18) examined the questions and classified into four types. The first type is questions concerning factual matters, that is, the questions beginning with "what". The second type is questions of inference beginning with "how" and "why" like the students ask in the classroom interaction.

\section{The Reason for the Teacher in the Use of Code Mixing and Code Switching in Learning Achievement}

In order to find out the reason for the teacher code mixing and code switching in learning achievement. The writer used structured interview. It means that the writer establish the questions before interviewing the teacher. The result of interview point out three reasons of the teacher in the use of code mixing and code switching in learning particularly in the classroom interaction namely to give clear explanation to the students, to make the students easy to understand, and make the teacher and the students close to each other.

\section{The Students' Preference towards the Use of Code Mixing and Switching in the Students Learning Achievement}

The students' preference towards the use of code mixing and code switching in the students learning achievement consist of two main points namely:

1. The use of code mixing and switching in the classroom interaction enhancing the students' scores in learning Biology. It is proved in the findings of the mean score of the students in doing Biology Achievement Test. In the findings given, the mean score of students are varieties seems the mean score of the students who have the highest type token ratio towards the use of code mixing and code switching of the students in learning achievement has the highest mean score that is class VIIA (81.11) and the type token ratio of this class is 0.764 . Then, the class VIIC who has mean score 73.70 and the type token ratio is 0.650 , and the class VIIE who has the mean score 68.52 and the type token ratio is 0.630 . 
2. The use of code mixing and switching convince positive attitude and positive role to the students' preference towards the use of code mixing and switching the students in learning achievement. It is proved in the findings of the mean score of the students in answering the Attitude questionnaire in the last meeting. In the findings given, the mean score of students are varieties but the mean score of those classes mostly give positive attitude to the students seems the mean score of the students towards the use of code mixing and code switching of the students in learning achievement has the mean score in class VIIA is 52.30, the mean score in class VIIC is 49.81, and the mean score in the class VIIE is 49.26. In fact, the mean score of the students' attitude has the highest mean score in class VIIA and the lowest mean score of the students' attitude is in the class VIIE. It is related to the score of the students in learning achievement that the highest mean score is the class VIIA.

Related to the main points above, it has relation with the students' preference towards the use of code mixing and code switching in learning achievement. The relation are the reason of the students who are choose the Indonesian/English code mixing and code switching in learning Biology in the classroom interaction. Many students choose Indonesian/English code mixing and code switching in their learning because of the reason below:

1. "My biology teacher teaches Biology in a clear and understandable way when she used Indonesian language".

2. "My Biology teacher makes Biology very interesting".

3. "Learning Biology in English increases my chances of passing English lesson".

4. "Learning Biology in English increases my chances of getting a good job after leaving school".

\section{Conclusions}

1. The type token ratio in code mixing and code switching Indonesian/English in classroom interaction varied. It reveals with the vocabulary used by the teacher varied. It is related to the teacher view about their students. She mixed and switched the language put in the situation in the classroom interaction.

2. The speech of the teacher in code mixing and code switching Indonesian/English when addressing students in the classroom contained longer utterances. It is related to the teacher function of speaking related to the use of code mixing and code switching the language in the classroom interaction.

3. There are two types of questions the teacher asked in code mixing and code switching the words in the classroom namely convergent and divergent questions. 
4. The teacher provided interactional feedback in code mixing and code switching to her students when addressing students in the classroom.

5. There are three reasons why the teacher mix and switch the code in the classroom interaction namely to give clear explanation to the students, to make the students easy to understand, and make the teacher and the students close to each other.

6. There are two roles of students in response the question namely the role of students to the teacher (S-T) and the role of students to students (S-S) in code mixing and code switching in the classroom interaction.

7. There are two types of the students question in code mixing and switching Indonesian/English when asked the teacher namely procedural questions and convergent questions.

8. The students' preference towards the use of code mixing and code switching in the students learning achievement consist of two main points namely (1) the use of code mixing and switching convince positive attitude and positive role to the students preference towards the use of code mixing and switching the students in learning achievement and (2) the use of code mixing and switching in the classroom interaction enhancing the students score in learning Biology.

\section{Suggestions}

Since the use code in bilingual school namely code mixing and code switching have been used in enhancing the students learning achievement and give positive role to the students' attitude, the researcher would like to give suggestions as follows:

1. The question, feedback, and correction of the teacher in applying codes make the students easy to give response in learning achievement. Since this research just limited to the use of code mixing and code switching in learning Biology. So, the writer suggests the other researchers to conduct furthermore research related to the use of code mixing and code switching to the other kinds of the lessons.

2. Since this research talk about the students' preference toward the use of code mixing and code switching in learning Biology. The other researcher is suggested to conduct furthermore research about the use of code mixing and code switching related to the level of students' intelligence with divided the students into lower, middle, and high level in learning Biology and English.

3. The following lines convey three recommendations. The first is addressed to the English teacher dealing with the classroom interaction by the use of code mixing and code switching in improving the students' preference in learning. The second is addressed to the English foreign language-teaching researchers. The third the is addressed to the contribution of our government in making bilingual school to be succeed in the future and make our country go forward. 


\section{BIBLIOGRAPHY}

Aghneta, O. U. A. 2008. "Code Switching in Interviews". Dissertation. Faculty of languages and linguistics. University of Malaya: Kuala Lumpur

Brice, A. 2000. "Code Switching and Code Mixing in the ESL Classroom: A Study of Pragmatic and Syntactic Features". Advances in Speech Language Pathology, Journal of the Speech Pathology Association of Australia, 20(1), 19-28.

Brown, D. 1994. "Teaching by Principle; an Interactive Approach to Language pedagogy”. New Jersey: Prentice-Hall. Lnc.

Chaudron, C. 1988. "Second Language Classrooms: Research on Teaching and Learning”. Cambridge: Cambridge University Press

Cook, V. 2000. Second Language Learning and Language Teaching (2nd Edition). Beijing: Foreign Language Teaching and Research Press.

Duran, Louise. "Toward a Better Understanding of Code Switching and Interlanguage in Bilinguality”. World Wide. (Online). (Web: http://www.ncela.gwu.edu/pubs/jeilm/vol14/duran) htm retrieved 15 January 20113

David.N. 1991. "Language Teaching Methodology: a textbook for Teachers". Cambridge: Cambridge University Press.

Ellis, R. 2003. "Second Language Acquisition" in H.G Widdowson (ed.) "Oxford Introduction to Language Study" New Edition, Oxford University Press: United Kingdom.

Garcia, Ana Linareas .2005. "The effect of teacher feedback on efl learners' functional production in classroom discourse" Anglogermanica (Online) (http://anglogermanica.uv.es:8080/Journal/Viewer.aspx?Year=2005\&ID=1lina res.pdf) retrieved February 1, 2013 
Gay, L. R, Geoffrey, E. Mills, and Peter, Airasian. 2006. "Educational Research: Competencies for Analysis and Application." New Jersey: Pearson Education, Inc.

Gumperz, J. J. (1982). “Conversational Code Switching”. In Discourse Strategies. Cambridge, England: Cambridge University Press.

Hamers, F.J \& Blanc, H.A.M. 2000. Bilinguality and Bilingualism. Cambridge: Cambridge University Press.

Heaton, J.B. 1988. “Writing English Language Test.” Newyork: Longman Group UK Limited. 101

Hudson, R, A. 1987. "Sociolinguistics". New York: Cambridge University Press

Hymes. D. H. (1964) " The Ethnography of Speaking”. $2^{\text {nd }}$ Edition

Ike. A. 2010. "Teacher Talk in the Classroom Interaction" A thesis. Graduate Program State University of Makassar: Makassar

Jack.C.R.(2002). "Curriculum Development in Language Teaching". Cambridge: Cambridge University Press.

Jeffrey.M.1997. "A Minimalist Approach to Intrasentential Code Switching: SpanishNahuatl Bilingualism in Central Mexico" A Dissertation: University of California

Kaelan. (2009). "Filsafat Bahasa Semiotika dan Hermeneutika". Paradigma: Yogyakarta

Krashen. S. D.1985. "Principles and Practice in Second Language Acquisition". University of Southern California. Pergamon Press: New York.

Lin, Hsin-Yin. 2005. "Teacher Talk of Native and Non-Native English Teachers in Efl Classroom". (Online) (http://ethesys.lib.mcu.edu.tw/ETD-db/ETD-searchc/getfile?URN=etd-0722105-220613\&filename=etd-0722105-220613.pdf).

Retrieved on February 1, 2013

Ludmila.I. at all. 2009. "Multidisciplinary Approach to Code Switching" in J. Benjamin (ed.) "Studies in Bilingualism", vol. XXXXI, Philadelpia: USA

M.O.Aeyomoni.2006. "Code-Switching and Code-Mixing: Style of Language Use in Childhood in Yoruba Speech Community" Obafemi Awolowo University: Nigeria 
Monique. B. 2002. "Motivation to Learn" IBE, Publications Unit Geneva 20, Switzerland.

Muh. Kholiq. 2004. "Code and Code Switching within Conversation at Gunadarma University Jakarta, Especially the Faculty of Letters, which is a Complex Community Especially in their Use of Language" Unpublished Thesis. Gradute Program. Universitas Gadjah Mada: Yogyakarta

Olugbara, C. T.2008. "The Effect of Isizuluienglish Code Switching as a Medium of Instruction on Students' Performance in and Attitudes towards Biology". Faculty of Education University Of Zululac

Owen. D. 1996. "Do Teachers Modify their Speech According to the Proficiency of their Students? ” ELTED Journal Vol.2 No. 1 Online. Retrieved on February 1,2011

Puasa, K. 2010. "Classroom Talk in Bilingual Class Interaction". Unpublished Thesis. Graduate Program State University of Makassar: Makassar

Rebecca,W.S.2008. "Code-Switching: Critical Thinking Strategies for Teaching Standard English in Urban Classrooms". Educational Leadership.

Rodgers and Richards .2001."Approaches and Methods in Language Teaching" Cambridge University press: United Kingdom.

Tedick, Diane J and Barbara de Gortari.1998." Research on error correction and implications for classroom teaching" ACIE Newsletter Volume 1 Number 3. (Online). (http://www.carla.unm.edu/immersion/acie/vol1/bridge.3.pdf) retrieved on January 152013

Then,D. C. \& Ting, S.H. 2009"A Preliminary Study of Teacher Code-switching in Secondary English”. Journal Volume 13, Number 1

Wardhaugh, Ronald.2006."An Introduction Sociolinguistics". Blackwell Publishing Ltd: United Kingdom.

Walsh. S. 2006. “Investigating Classroom Discourse”. Routledge: New York

Yan, Xiao. 2006. "Teacher Talk and EFL in University Classrooms". Online (www.asian-efl-jounal.com/thesisMaXiou.pdf) retrieved November 122013 
Zakaria, Razimi .2009. "Role of Code Switching in the Talk of Primary School Mathematics and Science Teachers" Universiti Putra Malaysia: Kuala Lumpur

Zaifuddin.2004."Code Switching and English Speaking Fluency: With Special Reference to Classroom Discussion." Unpublished Thesis.. Makassar: The State University of Makassar.

Psillos, S. 2010. The Routledge Companion to Philosophy of Science. Routledge.

Lemos, N. 2007. An Introduction to the Theory of Knowledge. Cambridge University Press.

Suriasumantri, J.S. 1981. Systemic Thinking. Binacipta.

White, Alan, R. 1982. The Nature of Knowledge. Rowman and Littlefield Press.

Quine, Willard Van Orman. 1961. From a Logical Point of View: Logico Philosophical Essays. New York: Harper \& Row.

Asrifan, A. (2009). Using songs in teaching English language for the young learners. ParePare: unpublished.

Puasa, K., Asrifan, A., \& Chen, Y. (2017). Classroom Talk in Bilingual Class Interaction. Research in Pedagogy, 7(1), 106-121.

Nadirah, N., Tahir, M. H., \& Asrifan, A. (2019). THE ABILITY TO TRANSLATE ENGLISH PHRASES INTO INDONESIAN AND THE DIFFICULTIES FACED BY THE ELEVENTH GRADE STUDENTS OF SMAN 1 PANCARIJANG. JOURNAL OF ADVANCED ENGLISH STUDIES, 2(1), 41-46.

Apdy, A. P. R., \& Asrifan, A. (2019, April). The Chinese mime game in teaching vocabulary on EFL classroom. In PROCEEDINGS OF THE 65th TEFLIN INTERNATIONAL CONFERENCE (Vol. 65, No. 01).

Taslim, T., Asrifan, A., Chen, Y., \& Nurdania, N. R. (2019). CORRELATION BETWEEN STUDENT'S VOCABULARY MASTERY AND SPEAKING SKILL. JOURNAL OF ADVANCED ENGLISH STUDIES, 2(2), 65-76.

Muthmainnah, M., Asrifan, A., Al Yakin, A., \& Sahabuddin, C. (2019, April). The use of dictogloss technique on ELT classroom: An experiment study of students listening comprehension. In PROCEEDINGS OF THE 65th TEFLIN INTERNATIONAL CONFERENCE (Vol. 65, No. 01).

Mutmainnah, M., Azis, S., Maulidya, U., \& Asrifan, A. (2017). Glory Style in Mandar Song Lyrics: A study of Mandar Tribe in South Sulawesi, Indonesia. JOURNAL OF ADVANCES IN LINGUISTICS, 8(1), 1286-1291.

Asrifan, A., Rinantanti, Y., Tang, S., \& Nadirah, N. (2019). THE 3-DIMENSION PICTURES IN INCREASING THE STUDENTS ABILITY AND INTEREST TO WRITE DESCRIPTIVE COMPOSITION. JOURNAL OF ADVANCED ENGLISH STUDIES, 2(1), 19-30. 
Asrifan, A., Nadira, N., \& Haedar, H. (2018). IMPROVING STUDENTS'READING COMPREHENSION OF DESCRIPTIVE TEXT THROUGH COLLABORATIVE MURDER. JOURNAL OF ADVANCED ENGLISH STUDIES, 1(2), 21-31.

Asrifan, A. (2015). Analysis of English Students' Learning Style in Bilingual Class. International Journal of Literature and Arts, 3(4), 34.

Farahdiba, S., \& Asrifan, A. (2016). Speaking Ability and Psychological Barriers of the Second Year Students of Hotel Department of SMKN 1 Sidenreng Kabupaten Sidrap in Speaking English. Asian EFL Journal, (89), 41.

Asrifan, A. (2012). Increasing the Students Ability to Write Descriptive Composition at SMP Negeri 13 Parepare by using the 3-Dimension Pictures.

Tang, S., Asrifan, A., Chen, Y., Haedar, H., \& Agussalim, M. (2019). THE HUMOR STORY IN TEACHING READING COMPREHENSION. JOURNAL OF ADVANCED ENGLISH STUDIES, 2(2), 77-87.

Nurwanti, N., Asrifan, A., \& Haedar, H. (2019). THE APPLICATION OF COOPERATIVE LEARNING: JIGSAW II TECHNIQUE IN IMPROVING STUDENTS'READING COMPREHENSION OF EXPOSITORY TEXT. JOURNAL OF ADVANCED ENGLISH STUDIES, 2(1), 31-40.

Asrifan, A. (2016). The Effectiveness of Think-Pair-Share Technique in Improving Studentsâ€ $€^{\mathrm{TM}}$ Speaking Ability and Interest. English Literature and Language Review, 2(3), 24-35.

Asrifan, A., Muthmainnah, M., Al-Yakin, A., Sahabuddin, C., \& Haedar, H. (2018). THE CAUSE-EFFECT TECHNIQUE IN TEACHING RECOUNT WRITING. JOURNAL OF ADVANCED ENGLISH STUDIES, 1(2), 63-72.

Asrifan, A., Vargheese, K. J., Syamsu, T., \& Amir, M. (2020). ESP COURSE DESIGN: THE NEED ANALYSIS ON TOURISM DEPARTMENT IN INDONESIA VOCATIONAL HIGH SCHOOLS. JOURNAL OF ADVANCED ENGLISH STUDIES, 3(2), 69-77.

Asrifan, A., Ghofur, A., \& Azizah, N. (2020). Cheating Behavior in EFL Classroom (A Case Study at Elementary School in Sidenreng Rappang Regency). OKARA: Jurnal Bahasa dan Sastra, 14(2), 279-297.

Nadirah, N., Asrifan, A., Vargheese, K. J., \& Haedar, H. (2020). INTERACTIVE MULTIMEDIA IN EFL CLASSROOM: A STUDY OF TEACHING READING COMPREHENSION AT JUNIOR HIGH SCHOOL IN INDONESIA. JOURNAL OF ADVANCED ENGLISH STUDIES, 3(2), 131145.

Muthmainnah, A. R., Atmowardoyo, H., Salija, K., \& Asrifan, A. (2020). Literary Work as Teaching Materials: A Study of Students and Lecturers Needs Analysis. Solid State Technology, 63(5), 394-407.

Tilome, A. A., Agustang, A., Jasruddin, M. S., \& Asrifan, A. (2020). Social Exchange of Political Elites in the Regional Leader Election of Gorontalo Province, Indonesia. Solid State Technology, 63(5), 521-531. 
Pacinongi, A., \& Asrifan, A. (2020). Bimbingan Pengawas Berkelanjutan dalam Mewujudkan Pendidikan Karakter Bangsa dalam Kegiatan Belajar Mengajar Penjaskes. Celebes Education Review, 2(1), 1-7.

Gunawan, G., \& Asrifan, A. (2020). Penerapan Kerja Kelompok Kegiatan MGMP Guru Ekonomi dalam Menyusun RPP untuk Meningkatkan Kompetensi Pedagogik. Celebes Education Review, 2(1), 31-36.

Yusuf, I., \& Asrifan, A. PENINGKATAN AKTIVITAS KOLABORASI PEMBELAJARAN FISIKA MELALUI PENDEKATAN STEM DENGAN PURWARUPA PADA SISWA KELAS XI IPA SMAN 5 YOGYAKARTA. Editorial Team, 32.

Al Yakin, A., Sahabuddin, C., Rahayu, A., Fitrah, N., \& Arifin, M. (2020). Political Celebrification and Electability: A Study of Political Phenomena Imaging in Election Polewali Mandar District, West Sulawesi, Indonesia. Solid State Technology, 63(5), 632-646.

Junaedah, S. B. T., \& Ahmad, M. A. (2020). The Outdoor Learning Modules Based on Traditional Games in Improving Prosocial Behaviour of Early Childhood. International Education Studies, 13(10). 